\title{
Inculcating National Values for Students' Character Building of the Faculty of Social and Political Sciences Sangga Buana University through Campus Extracurricular Program
}

\author{
H. Muchsin al-Fikri ${ }^{1}$, Yuyun Yuniarsih ${ }^{2}$, Tresia Wulandari ${ }^{3}$ \\ Universitas Sangga Buana ${ }^{1,2}$, Universitas Pasundan Bandung Indonesia ${ }^{3}$ \\ muchsinalfikri2020@gmail.com¹, yuyunyuniarsih79@gmail.com², \\ tresiawulandari12@gmail.com ${ }^{3}$
}

\section{Article History}

accepted 23/03/2021

approved 10/04/2021

published 20/04/2021

\begin{abstract}
Students are a generation full of potential and achievements. Education at the University should encourage them to develop their hidden potential to become the successor and continuation of national development. Unfortunately, the cultivation of national values is still limited to transfer of knowledge and has not yet reached the transfer of value. Each student has a unique potential that can be developed according to their background and characteristics. There are those who have the potential to become leaders, there are also those who tend to be adaptable and good at establishing interpersonal relationships with other people. But not a few also have temperamental. So it is not uncommon for them to be radical and rebellious. This is where the importance of cultivating the value of nationality so that his critical power is channeled to defend and love his country. This research discusses the program of inculcating national values for the formation of student character carried out by the Faculty of Social and Political Sciences at Sangga Buana University through extra-curricular activities. This research is a descriptive qualitative research with a case study approach.
\end{abstract}

Keywords: national values, character building, extra curricular

\begin{abstract}
Abstrak
Mahasiswa adalah generasi yang sarat akan potensi dan prestasi. Pendidikan di Universitas seharusnya mendorong mereka untuk mengembangkan potensi yang tersembunyi menjadi penerus dan pelanjut perbangunan bangsa. Sayangnya, penanaman nilai kebangsaan masih sebatas transfer knowledge dan belum sampai kepada transfer of value. Setiap mahasiswa memiliki potensi unik yang bisa dikembangkan sesuai dengan latar belakang dan karakteristiknya. Ada yang memiliki potensi menjadi pemimpin, ada juga yang cenderung mudah beradaptasi dan pandai menjalin hubungan interpersonal dengan orang lain. Namun tidak sedikit juga yang memiliki temperamental. Sehingga tidak jarang mereka bersikap radikal dan memberontak. Disinilah pentingnya penanaman nilai kebangsaan agar daya kritisnya disalurkan untuk membela dan mencintai negaranya. Penelitian ini membahas tentang program penanaman nilai kebangsaan untuk pembentukan karakter mahasiswa yang dilakukan oleh FISIP Universitas Sangga Buana melalui ekstra kurikuler. Penelitian ini adalah penelitian kualitatif deskriptif dengan pendekatan studi kasus.
\end{abstract}

Kata kunci: nilai kebangsaan, carakter building, ekstra kulikuler

Social, Humanities, and Education Studies (SHEs): Conference Series https://jurnal.uns.ac.id/shes

p-ISSN 2620-9284

e-ISSN 2620-9292 


\section{PENDAHULUAN}

Memasuki era Society 5.0 negara Indonesia masih dihadapkan dengan problematika yang sangat rumit hampir di segala bidang mulai ekonomi, pendidikan, sosial, moral dll. Bidang ekonomi misalnya kita dihadapkan kepada masih tingginya angkat kemiskinan, korupsi yang merajalela. Di bidang pendidikan kita mengalami ketidakmerataan pendidikan, tawuran antar pelajar dan mahalnya biaya pendidikan.

Dan yang paling krusial adalah terjadinya demoralisasi yang melanda kalangan masyarakat wabil khusus kalangan pelajar dan mahasiswa. Kita akan merinding apabila menyaksikan lewat layar kaca dan media informasi yang menayangkan bagaimana krisis moral ini sudah menular dan menggerogoti generasi penerus bangsa ini. Demoralisasi berupa anarkisme, video porno, penyalahgunaan narkoba, seks bebas dll.

Sedangkan kita semua menyadari bahwa mahasiswa telah disiapkan menjadi penerus bangsa yang akan membangun, melanjutkan dan memajukan bangsa Indonesia kelak di masa depan. Merekalah yang menjadi bibit-bibit pejuang selanjutnya yang menjadi agent of Change di segala bidang dan menjadi social control yang akan terus menjunjung tinggi keterbukaan dan transparansi dalam melaksanakan pemerintahan supaya lebih mensejahterakan rakyatnya dan meminimalisir penyelewengan aparatur negara. Mereka adalah generasi harapan yang kelak mampu membawa perubahan bagi negara Indonesia untuk bisa bersaing dengan negaranegara di dunia.

Bangsa kita hari ini juga tengah dihadapkan kepada permasalahan yang sangat kompleks diantaranya ;

1. Melemahnya pemahaman, penghayatan dan pengamalan Pancasila.

2. Melemahnya pemahaman dan kesadaran terhadap nilai-nilai Budaya Bangsa Indonesia.

3. Penerapan sistem hukum kurang baik.

4. Penyelenggaraan negara dan masyarakat kurang peka dan peduli perkembangan sosial yang menyebabkan konflik sosial.

5. Rendahnya ketahanan masyarakat terhadap pengaruh negatrif globalisasi.

6. Melemahnya pewarisan dan implementasi nilai-nilai luhur bangsa (budaya bangsa Indonesia)

7. Menurunnya wawasan kebangsaan.

\section{Pengertian Karakter}

Karakter adalah watak, tabiat, akhlak, atau kepribadian seseorang yang terbentuk dari hasil internalisasi berbagai kebajikan yang diyakini dan digunakan sebagai landasan untuk cara pandang, berpikir, bersikap dan bertindak. (Kemendiknas, Rencana Aksi Pendidikan Nasional Pendidikan Karakter, (Jakarta: Balitbang dan Puskur, 2010), hal.3

Karakter adalah seperangkat sifat yang selalu dikagumi sebagai tanda-tanda kebaikan, kebajikan dan kematangan moral seseorang. Secara etimologi, istilah karakter berasal dari bahasa Latin 'character' yang berarti watak, tabiat, sifat-sifat kejiwaan, budi pekerti, kepribadian dan akhlak.

Untuk menambah wawasan kita ada baiknya kita simak pandangan ebberapa ahli:

1. Menurut Poerwadarminta, karakter berarti tabiat, watak sifat-sifat kejiwaan, akhlak atau budi pekerti yang membedakan seseorang dengan orang lain (Syarbini, 2012:13).

2. Menurut Shimon Philips, karakter adalah kumpulan tata nilai menuju pada suatu sistem, yang melandasi pemikiran, sikap dan perilaku yang ditampilkan (Fathul Muin, 2011:160). 
3. Menurut Coon, karakter adalah suatu penilaian subjektif terhadap kepribadian seseorang yang berkaitan dengan atribut kepribadian yang dapat atau tidak dapat diterima oleh masyarakat (Zubaedi, 2011:8).

4. Menurut Mansur Muslich (2010:70), karakter adalah cara berfikir dan berperilaku seseorang yang menjadi ciri khas dari tiap individu untuk hidup dan bekerjasama, baik dalam keluarga, masyarakat dan negara.

Adapun unsur-unsur karakter terdiri dari sikap, emosi, kepercayaan, kebiasaan dan kemauan dan konsepsi diri. Karakter tersebut tidak mungkin muncul begitu saja tanpa diterapkan melalui proses pendidikan yang sangat panjang. Maka dikenallah apa yang disebut pendidikan karakter. Pendidikan karakter adalah usaha sadar dan terencana yang dapat dilakukan baik oleh pemerintah, masyarakat, sekolah maupun orang tua untuk membentuk kepribadian dan tingkah laku seseorang sebagai landasan berpikir, bersikap dan bertindak dalam interaksinya terhadap Tuhan Yang Maha Esa, diri sendiri, orang lain maupun lingkungan.

Ada 18 nilai pembentuk karakter dalam mata kuliah yaitu ; 1. Religius, 2. Jujur, 3. Toleransi, 4. Disiplin, 5. Kerja Keras, 6. Kreatif, 7. Mandiri, 8. Demokratis, 9. Rasa ingin tahu, 10. Semangat kebangsaan, 11. Cinta tanah air, 12. Menghargai prestasi, 13. Bersahabat/Komunikatif, 14. Cinta Damai, 15. Gemar membaca, 16. Peduli lingkungan, 17. Peduli sosial dan 18. Tanggungjawab.

\section{Esensi Nilai Kebangsaan}

Nilai-nilai kebangsaan diambil dari sumber Pancasila, UUD 45, NKRI dan Sesanti Bhineka Tunggal Ika. Adapun esensi nilai kebangsaan berupa : 1. Nilai religius, 2. Nilai kekeluargaan, 3. Nilai keselarasan, 4. Nilai kerakyatan, 5. Nilai keadilan, 6. Demokrasi, 7. Kesamaan derajat, 8. Ketaatan hukum, 9. Kesatuan Wilayah, 10. Persatuan bangsa, 11. Kemandirian, 12. Toleransi, 13. Keadilan dan 14. Gotong royong.

Adapun menurut situs resmi Kementerian Pendidikan dan Kebudayaan RI, sikap positif yang sesuai dengan nilai-nilai kebangsaan adalah : 1. Nilai religius, 2. Nilai kemanusiaan, 3. Nilai produktivitas, 4. Nilai keseimbangan, 5. Nilai demokrasi, 6. Nilai kesamaan derajat dan 7. Nilai Ketaatan hukum.

Nilai religius berisi percaya dan takwa kepada Tuhan Yang Maha Esa sesuai agama dan kepercayaan masing-masing menurut dasar kemanusiaan yang adil dan beradab. Hormat menghormati serta bekerjasama antara pemeluk agama dan penganut-penganut kepercayaan yang berbeda-beda sehingga terbina kerukunan hidup. Saling menghormati kebebasan menjalankan ibadah sesuai dengan agama dan kepercayaan masing-masing. Tidak memaksakan suatu agama atau kepercayaan kepada orang lain.

Nilai kemanusiaan berisi ; mengakui persamaan derajat, hak dan kewajiban antara sesama manusia. Saling mencintai sesama manusia. Mengembangkan sikap tenggang rasa. Tidak semena-mena terhadap orang lain, menjunjung tinggi nilai kemanusiaan, berani membela kebenaran dan keadilan, bangsa Indonesia sebagai bagian dari masyarakat dunia internasional maka harus mengembangkan sikap saling hormatmenghormati dan bekerjasama dengan bangsa lain.

Nilai produktifitas berisi : perlindungan terhadap masyarakat dalam beraktivitas menuju kemakmuran, sarana dan prasarana yang mempu mendorong masyarakat untuk kreatif dan produktif dan terciptanya Undang-undang untuk meningkatkan kesejahteraan masyarakat.

Nilai keseimbangan berisi menjalankan hak dan kewajiban sebagai warga negara yang proporsional, tidak memaksakan kehendak, saling toleransi, tolong menolong, rukun, damai, menghormati perbedaan agama dan kepercayaan, persahabatan serta 
membela dan melindungi yang lemah. Keseimbangan antara kehidupan jasmani dan rohani.

Nilai demokrasi berisi : 1. Kedaulatan berada di tangan rakyat, berarti setiap warga negara memiliki kebebasan yang bertanggungjawab terhadap penyelenggaraan pemeriontahan sehingga dapat terwujud persatuan dan kesatuan Indonesia. 2. Pilar utama dalam membangun persatuan dan kesatuan bangsa dalam masyarakat adalah sbb : Rasa cinta tanah air, jiwa patriot bangsa, tercapainya kesejahteraan bagi seluruh rakyat Indonesia, pemahaman yang benar atas realitas adanya perbedaan dalam keberagaman. Dan tumbuhnya kebanggaan sebagai bangsa Indonesia.

Nilai kesamaan derajat berisi : setiap warga negara memiliki hak, kewajiban dan kedudukan sama di depan hukum. Nilai ketaatan hukum berisi setiap warga negara tanpa pandang bulu wajib menaati setiap hukum dan peraturan yang berlaku. Lembaga-lembaga penegak hukum juga wajib menaati hukum dan peraturan yang berlaku.

Untuk meredam dan meminimalisir demoralisasi serta permasalahan di atas diperlukan upaya serius menanamkan nilai-nilai agama dan nilai kebangsaan. Penanaman nilai baik nilai agama ataupun kebangsaan memerlukan waktu yang sangat panjang melalui proses pendidikan baik formal maupun non formal, melalui kurikuler maupun ekstra kurikuler.

Penelitian ini akan mendeskripsikan upaya-upaya penanaman nilai kebangsaan untuk membentuk karakter mahasiswa yang dilakukan oleh Universitas Sangga Buana melalui kegiatan ekstra kurikuler.

\section{METODE}

Penelitian ini adalah penelitian kualitatif deskriptif dengan pendekatan studi kasus. Peneliti melakukan depth interview kepada para informan yang sangat memahami kondisi seperti Direktur Kemahasiswaan, Dekan Fisip Universitas Sangga Buana dll.

\section{HASIL DAN PEMBAHASAN}

Universitas Sangga Buana Bandung sebagai kampus perjuangan yang membentuk mahasiswa patriot yang berakhlaq mulia dan memiliki wawasan kebangsaan yang paripurna. USB Bandung menekankan pentingnya membangun karakter mahasiswa melalui proses pendidikan baik intra kurikuler maupun ekstra kerikuler. Hal tersebut sesuai dengan fungsi pendidikan masa kini yang tidak hanya terbatas pada penyebaran dan pengembangan ilmu semata. Sebagai bagian dari pendidikan secara umum, perguruan Tinggi pun diharapkan turut serta membangun karakter kepada mahasiswanya.

Tantangan bagi Universitas Sangga Buana tidak hanya datang dari kebutuhan akan pribadi kebangsaan dalam peserta didik, tapi juga perubahan yang terjadi dalam dunia secara global. Dengan percepatan perkembangan teknologi dan dunia maya, seringkali melahirkan efek distruptif saat semua pihak didorong untuk beradaptasi dengan perubahan. USB kini tidak hanya dituntut menjadi laboratorium ilmu, namun juga laboratorium kemanusiaan. Pengembangan karakter sesuai dengan pandangan dan nilai-nilai kebangsan menjadi sangat penting. Lulusan USB diharapkan menjadi manusia humanum, menghargai keberagaman serta memiliki daya saing maupun kemampuan berkolaborasi dalam menyongsong era global.

Untuk memudahkan penanaman nilai kebangsaan kepada para mahasiswanya, menurut Direktur Kemahasiswaan Reza, USB membentuk lembaga-lembaga kemahasiswaan seperti BEM, DPPM, senat mahasiswa FE, FT, dan FISIP, Himpunan mahasiswa manajemen, himpunan mahasiswa akuntansi, himpunan mahasiswa sipil, himpunan mahasiswa teknik industri, himpunan mahasiswa sistem informasi dan informatika, himpunan mahasiswa teknik mesin, himpunan mahasiswa teknik elektro, 
himpunan mahasiswa ilmu komunikasi, himpunan mahasiswa bisnis, ukm basket, himpunan mahasiswa pecinta alam, resimen mahasiswa, ukm taekwondo, ukm futsal, ukm creasa, ukm teater, ukm arumba, ukm DKM, komunitas pena sangga buana, komunitas rana fotografi, komunitas pramuka, komunitas sbetv, komunitas hipmi PT. Semua lembaga tersebut dijadikan sarana untuk menanamkan nilai-nilai kebangsaan kepada mahasiswa.

Selain pembinaan melalui lembaga-lembaga ekstra kampus tersebut, USB juga menggelar beberapa event kegiatan seperti deklarasi Kampus anti Hoax dan Seminar Nasional Metode Penelitian. Kegiatan ini dilaksanakan pada hari Selasa, 15 Januari 2019 di Aula Serba Guna YPKP dengan menggandeng PDRI (Persaudaraan Dosen Republik Indonesia).

Selain itu USB juga menggelar Seminar Kebangsaan yang bertemakan Menanggulangi Bahaya Narkoba, Miras, Seks Bebas serta paham menyimpang. Seminar ini dilaksanakan pada Rabu, 14 Januari 2019 di Kampus USB YPKP Bandung.

\section{SIMPULAN}

Nilai nilai kebangsaan Berupa nilai yang diambil dari sumber budaya Indonesia berupa ketuhanan, kemanusiaan, persatuan, demokrasi, keadilan, pluralis dan multikultur serta patriotisme merupakan nilai budaya utama yang dibutuhkan dalam wawasan kebangsaan mahasiswa.

Wawasan dan nilai nilai kebangsaan ini telah ditanamkan kepada mahasiswa USB melalui berbagai macam pembinaan di lembaga-lembaga kemahasiswaan dan juga melalui Seminar dan diskusi.Kegiatan semacam pemantapan nilai kebangsaan, seperti yang dilakukan oleh kampus USB ini perlu terus dikembangkan dan mendapatkan apresiasi yang sebesar besarnya. Diskusi, seminar ataupun kegiatan training in door maupun out door perlu terus digalakan.

Dibutuhkan kerja keras dan usaha secara masive oleh seluruh stake holder sehingga Wawasan kebangsaan semakin baik dan ketahanan nasional semakin tangguh di kalangan mahasiswa.

\section{DAFTAR PUSTAKA}

Aqib, Zainal dan Sujak. (2011). Panduan dan Aplikasi Pendidikan Karakter. Bandung :

Yrama Widya

Kemdiknas, (2010). Desain Induk Pembangunan Karakter Bangsa. Jakarta: Kemdiknas.

Koesoema A, Doni, (2007). Pendidikan Karakter: Strategi Mendidik Anak di Zaman Global. Jakarta: PT Grasindo.

Koesoema A, Doni, (2012). Pendidikan Karakter Utuh dan Menyeluruh. Yogyakarta: Kanisius.

Lickona, Thomas, (2012). Educating for Character, Penerjemah Juma Abdu Wamaungo. Bandung: Remaja Rosdakarya.

Megawangi, Ratna, (2004). Pendidikan Karakter Solusi yang Tepat untuk Membangun Bangsa. Jakarta: BP Migas dan Star Energy.

Muin, Fatchul, (2011). Pendidikan Karakter: Konstruksi Teoritik dan Praktik. Jogjakarta: Ar-Ruzz Media.

Kementrian Pendidikan dan Kebudayaan RI. (2011). Peraturan Mendiknas tentang Satuan Pengawasan Internal (Permendiknas Nomor 47 tahun 2011). Jakarta: Penulis. 